LIAMES 4 - pp. 29-42, Primavera 2004

Vanessa Lea

(IFCH, UNICAMP)

\title{
Aguçando o entendimento dos termos triádicos Mẽbengôkre via aborígenes australianos: dialogando com Merlan e outros
}

\section{RESUMO}

O trabalho enfoca os termos triádicos encontrados na língua Mẽbengokre, com o intuito de estimular comparações com as demais sociedades Jê. Alguns antropólogos notaram a existência de tais termos, mas os consideraram circunlocuções, relativas à afinidade. $\mathrm{O}$ leque de termos que encontrei demonstra que não se limita a termos referentes aos afins. Tentei reduzi-los a uma espécie de equação, do tipo: 'meu filho = teu filho classificatório'. Após vinte anos sem conseguir avançar esta discussão, descobri termos análogos na Austrália, onde foram analisadas por F. Merlan e mais alguns autores.

Tais termos compõem uma série distinta dos termos básicos de referência e vocativos. Demonstram um requinte lógico, preenchendo uma lacuna semântica que falta em línguas como inglês ou português. Manifestam noções de geometria (ou etno-matemática), demonstrando, no caso Mẽbengôkre, a sofisticação de uma sociedade que há pouco mais de meio século atrás foi rotulada como 'marginal' à floresta tropical.

PALAVRAS CHAVE Mẽbengôkre; Termos triádicos; Vocativos; Merlan.

\section{ABSTRACT}

This paper focuses on the triadic terms that are found in the Mẽbengôkre language, in order to stimulate comparison with other Jê societies. Some anthropologists noted the existence of such terms, but considered them to be circumlocutions of affinity. The range of terms found shows that they are not limited to terms concerning affines. I tried to reduce them to a sort of equation, such as: 'my son = your classificatory son'. After being unable to advance this discussion for over twenty years, I came across analogous terms in Australia, where they were analyzed by F. Merlan and several other authors.

These terms constitute a series that is distinct from the basic reference and vocative terms. They manifest a sophisticated logic, filling in a semantic vacuum that is lacking in languages like English or Portuguese. They incorporate notions of geometry (or ethno-mathematics), demonstrating, in the Mẽbengôkre case, the complexity of a society that little over half a century ago was labeled as 'marginal' to the tropical forest.

KEYWORDS Mẽbengôkre ; Triadic terms; Merlan. 


\section{INTRODUÇÃO}

Desde 1981, estou intrigada com aquilo que denominei termos triádicos de parentesco Mẽbengôkre', (Lea 1986). Foram designados como termos indiretos ou circunlocuções de afinindade por alguns estudiosos dos Jê (vide Turner 1966, Vidal 1977, Seeger 1981). Pretendo argumentar que, na realidade, tratam-se de formas eminentemente lógicas, de aplicabilidade semântica universal. Levei até outubro de 1996, na semana Mẽbengôkre realizada no Museu Nacional (UFRJ), para encontrar um paralelo com tais termos em outras sociedades, embora sabia que um dia tal descoberta era praticamente inevitável, justamente em função de seu caráter lógico. Foi Marcela de Souza que percebeu a conexão entre o fenômeno dos termos que descrevi na minha palestra no Museu Nacional, e determinados termos encontrados entre alguns povos de aborígenes australianos, analisados mais detalhadamente por Merlan (1989), mas também descritos por Laughren (1982), McConvell (1982), e McGregor (1996), entre outros. ${ }^{2}$ Curiosamente, o caráter lógico do fenômeno não foi abordado diretamente pelos pesquisadores na Austrália.

\section{APROXIMANDOAOS TERMOSTRIÁDICOS}

Antes de conhecer a literatura sobre os termos australianos correspondentes, resolvi formular um diagrama (pg. seguinte) para tentar tornar os termos mẽbengôkre mais inteligíveis para não-especialistas. A semelhança entre meu diagrama, e aqueles referentes aos termos australianos (Laughren 1982: 73; Merlan 1989: 245; McGregor 1996: 226), reforça a analogia entre o fenômeno constatado, por enquanto, apenas no Brasil e na Austrália.

Utilizo a expressão termos triádicos, em relação aos Mẽbengôkre, por considerar (veja diagrama) que o eixo da base do triângulo é dado pelo ato da fala, ou seja, quando o locutor se dirige ao interlocutor. A partir desses dois pontos, as duas perspectivas convergem para um ponto comum, ou seja, o referente. Meu triângulo está de cabeça para baixo, porque coloco o locutor e interlocutor em primeiro plano, e o referente em segundo plano. No diagrama triangular de Laughren (1982), é o falante que ocupa o ápice do triângulo, e o interlocutor e referente as duas bases. Como no triângulo de McGregor (ver diagrama), o ápice está para cima. No diagrama de Laughren, uma

1

Utilizo a ortografia do Summer Institute of Linguistics (SIL), disseminada entre a subdivisão Mẽtyktire com quem trabalho desde 1978 (vide Stout e Thomson 1974). Há apenas duas exceções: não encontrei o contraste entre /ã/ e / $\tilde{\Lambda} /$, e escrevo /t $\int /$ como "tx", enquanto o SIL eliminou a letra " $\mathrm{t}$ ".

Segundo McConvell (1982: 100), uma das primeiras breves referências aos termos triangulares foi feita pelo etnólogo Meggitt, em relação aos Walpiri, numa publicação de 1962. Até 1982, McConvell conhecia apenas mais duas descrições publicadas, e uma não publicada. Merlan (1989: 230) atribuiu a McConvell (1982) a única descrição geral feita até então. McGregor (1996: 244, nota 1) comenta que aquilo que chama termos ternários foram designados de mais três maneiras por outros autores - triangulares, tri-relacionais, e termos de parentesco compartilhados. 
flecha aponta do locutor para o interlocutor, e outra do locutor para o referente; uma terceira flecha, na base do triângulo, conecta o interlocutor e o referente. ${ }^{3}$

Vidal (1977) merece crédito por ser o primeiro pesquisador a avançar a questão no que diz respeito aos Jê, apesar da designação "terminologia de referência indireta" (1977:58). ${ }^{4}$ Comecei investigando os termos triádicos a partir dos dados e a descrição feitos por ela, após ouvir regularmente termos que não constataram nas listas de termos de referência e vocativos apresentados por Dreyfus (1963), e Turner (1966). Aquilo que analiso como uma equação do tipo: 'tua sobrinha = minha filha', Vidal (1977: 58) explica com frases do tipo: "Mulher falando com seu irmão a respeito de sua própria filha". Isto é significativo porque, como na minha equação, partindo da formulação de Vidal, esta série de termos é interpretada como explicitando a relação entre o interlocutor e o referente, e entre o locutor e referente, mas deixa apenas implícita a relação entre locutor e interlocutor. A relação entre locutor e interlocutor deve ser evidente para eles na maioria dos casos, não precisando ser explicitada, e quando não for, seria deduzível, para eles, a partir da relação de cada um deles com o referente. Laughren (1982: 73) também afirma que "[s]e duas das relações são conhecidas, então a terceira pode ser deduzida." ${ }^{5}$

Merlan sugere (1989: 229) que "[a]s lexicalizações especiais podem ser comparadas com os termos comuns para determinar as semelhanças e diferenças existentes entre os dois sistemas". Dos vinte quatro termos triádicos que anotei, referentes às relações de consangüinidade e afinidade (excluindo a série de mais dezessete termos triádicos vinculadas à amizade formal), em apenas dois deles pode ser detectada alguma relação entre uma forma elementar (como 'pai') e a forma triangular. Os demais vinte dois termos são sui generis, no sentido em que não há nenhuma relação evidente entre um ou outro dos dois termos elementares implicados na relação triangular. ${ }^{6}$ Alguém pode indagar por quê infiro que um termo como aparidjwỳjtx significa 'tua sobrinha $=$ minha filha', quando o termo de referência básico para 'meu filho/a' é ikra ( $i$ - sendo o prefixo de primeira pessoa, e $a$ - o prefixo de segunda pessoa), e 'tua sobrinha' é atabdjwỳ (? falando para seu irmão, ou ? falando para sua irmã).

Melatti (1979:55) apresenta quatro termos de parentesco em Krahó que reconheci como cognatos para termos triádicos Mẽbengôkre, comprovando que o fenômeno em questão não se limita aos Mẽbengôkre e Suyá, sendo encontrado entre pelo menos uma das subdivisões Timbira. Os termos dados por Melatti, e Seeger, e seus cognatos Mẽbengôkre, são os seguintes:

\section{3} McConvell, $y$ é o propositus (que definimos em seguida), e $x$ é o referente, mas não ficou inteiramente claro para mim, portanto, omito seu diagrama aqui. O trabalho de Laughren (1982) é altamente técnica, e tenho uma cópia de apenas duas páginas.

Vidal (1977: 58-58) menciona dezenove termos triádicos referentes aos consangüíneos e afins, e mais seis termos triádicos referentes à amizade formal, um total de vinte cinco termos.

Todas as traduções de citações são minhas.

6 McConvell (1982:100) menciona que a maioria dos 'termos compartilhados' em Gurindji são formalmente não relacionados aos demais termos de parentesco; em poucos casos são idênticos a um termo não marcado, embora distinguíveis em termos semânticos e distribucionais. 


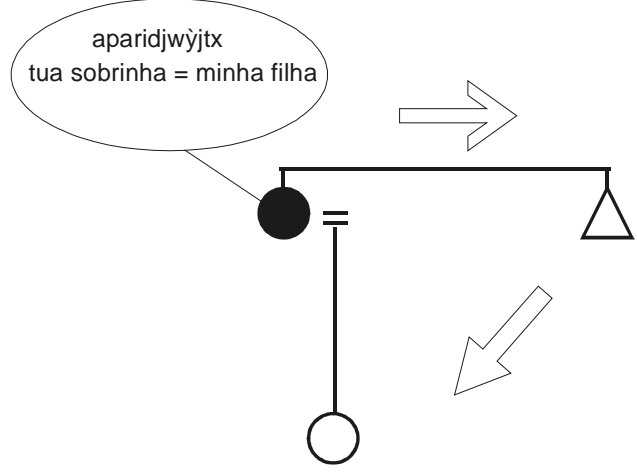

Diagrama dos termos multirelacionais Merlan (1989: 245)

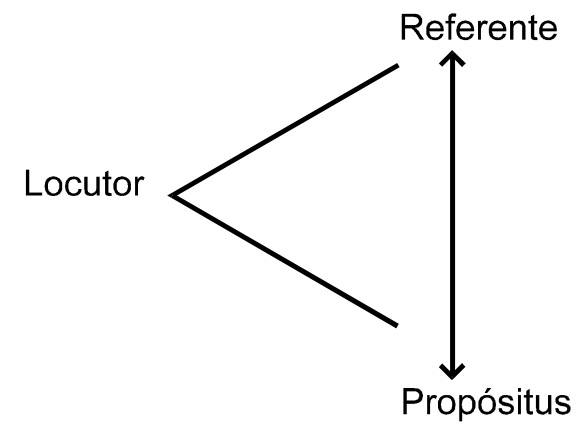

Diagrama dos termos ternários McGregor (1996: 226)

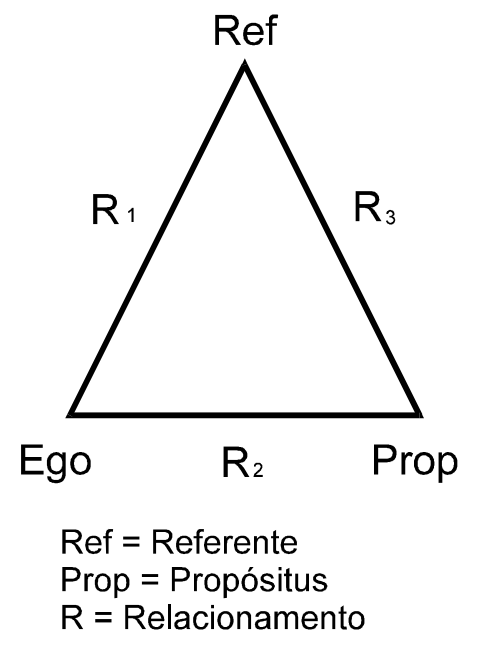


Tabela de Cognatos de alguns termos triádicos MẽbengôKre

\begin{tabular}{|l|l|l|l|}
\hline $\begin{array}{l}\text { TERMO } \\
\text { KRAHÓ }\end{array}$ & $\begin{array}{l}\text { GLOSA DE } \\
\text { MELATTI (1979: 55) }\end{array}$ & $\begin{array}{l}\text { COGNATO } \\
\text { MẼBENGÔKRE }\end{array}$ & GLOSA DE LEA \\
\hline akamtére & teu filho & akamrere & teu filho $=$ meu filho \\
\hline akatxwoi & tua filha & akadjwojtx & tua filha $=$ minha filha \\
\hline ia'para & $\begin{array}{l}\text { neto, ou sobrinho de } \\
\text { germano de sexo } \\
\text { oposto ao locutor }\end{array}$ & apari & $\begin{array}{l}\text { tua neta, ou sobrinha de } \\
\text { germano de sexo oposto ao } \\
\text { locutor }=\text { minha filha }\end{array}$ \\
\hline iapartxwoi & $\begin{array}{l}\text { neta, ou sobrinha de } \\
\text { germano de sexo } \\
\text { oposto ao locutor }\end{array}$ & aparidjwoj & $\begin{array}{l}\text { tua neta } \text { ou sobrinha de } \\
\text { germano de sexo oposto ao } \\
\text { locutor }=\text { minha filha }\end{array}$ \\
\hline
\end{tabular}

\begin{tabular}{|l|l|l|l|}
\hline $\begin{array}{l}\text { TERMO } \\
\text { SUYÁ }\end{array}$ & $\begin{array}{l}\text { GLOSA DE } \\
\text { SEEGER (1981: 134) }\end{array}$ & $\begin{array}{l}\text { COGNATO } \\
\text { MẼBENGÔKRE }\end{array}$ & GLOSA DE LEA \\
\hline a-tukà-yi & $\begin{array}{l}\text { termo indireto para pai } \\
\text { da esposa (sogro) }\end{array}$ & atukàye & teu pai $=$ meu sogro \\
\hline a-kot-tchï-yi & $\begin{array}{l}\text { termo indireto para } \\
\text { irmão da esposa } \\
\text { (cunhado) }\end{array}$ & akotki'e & $\begin{array}{l}\text { teu irmão/a }=\text { meu } \\
\text { cunhado/a, } \text { genro ou nora } \\
\text { etc. } \text { (ver Lea 1986: } \text { cap. } \text { V) }\end{array}$ \\
\hline
\end{tabular}

O fato de empregar o prefixo de segunda pessoa pode explicar porque vários pesquisadores confundiram os termos triádicos com termos comuns, ou circunlocuções de afinidade, traduzíveis apenas como 'tua sogra', 'teu genro' etc. McConvell (1982:100) nota que, embora haja um conjunto completo de termos compartilhados para todas as categorias de parentesco quando o ponto de referência (propositus) é a mãe da esposa (ou seja, uma relação de evitação), há muitos outros termos desse tipo sem conexão com evitação. Portanto "é melhor evitar de considerar os termos compartilhados meramente como um aspecto da linguagem de evitação." Isto vale igualmente no caso dos Mẽbengôkre.

A afirmação da natureza triádica de determinados termos Mẽbengôkre se baseia na série dos termos triádicos referente à amizade formal, onde a maioria é iniciada pelo prefixo de segunda pessoa ( $a$-), acrescido a um termo de referência básica como 'mãe' (nã). Quase todos os termos nesta série terminam em nget (forma masculina) ou ngetx (forma feminina), quando a pessoa a quem se refere é um primogênito, ou ngete (para ambos os gêneros) quando a pessoa nasceu no meio de um conjunto de germanos, ou quando é o caçula. Por exemplo, anãngetx/ anãngete significa 'tua mãe que é minha amiga formal'. Neste exemplo, não é fácil deduzir a relação entre locutor e interlocutor. Se for dito por um homem, poderia indicar a potencialidade de uma relação conjugal, já que os amigos formais são herdados do pai, e uma mulher detém a prerrogativa de eleger um dos amigos formais dela como cônjuge da filha. $\mathrm{O}$ amigo formal da mãe tem também o papel de disciplinar o/a filho/a dela quando faz mal criação; basta a mãe chamá-lo para assustar a criança. A amizade formal empenha um papel importante na vida cerimonial, incluindo os enterros, e foi tratada extensamente na literatura antropológica referente aos Jê. 
Nos dezessete termos triádicos referentes à amizade formal, cada um apresentando duas formas (conforme já descritas), cinco preservam o termo de referência básica, cinco termos apresentam formas intermediárias, onde o termo básico é modificado, mas ainda identificável, e sete termos não coincidem com o termo básico, embora em quatro destes casos o termo referente a um amigo formal é semelhante a um dos termos triádicos que não envolvem os amigos formais (não há espaço para aprofundar uma explicação possível aqui). ${ }^{7}$

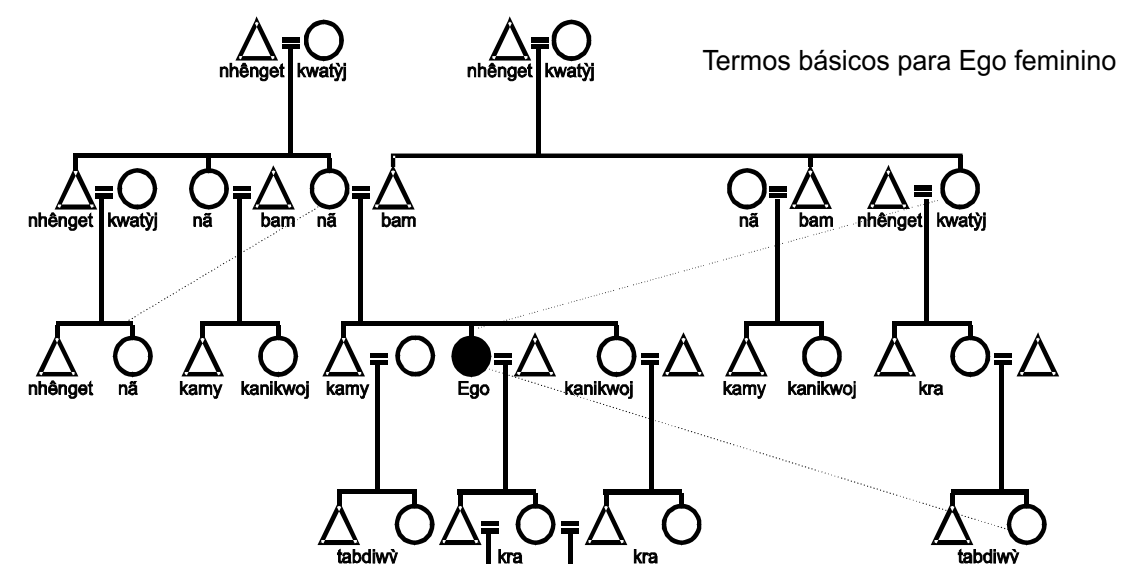

Glosa dos termos

nhênget = irmão da mãe, pai do pai, pai da mãe, filho do irmão da mãe kwatỳj = irmã do pai, mãe do pai e mãe da mãe tabdjwỳ = filhos do irmão, netos

\author{
nã = mãe, filha do irmão da mãe \\ bam $=$ pai \\ kamy = irmão \\ kanikwoj $=$ irmã \\ $\mathrm{kra}=$ filho/a, filhos da irmã, filhos da irmã do pai
}

As linhas quebradas indicam a transmissão de nomes. As linhas superiores indicam a transmissão de nomes de uma mulher para a filha do irmão. A linha inferior indica a devolução de nomes de uma mulher para a neta de sua nominadora. O que é significativo para entender a terminologia é que a lógica de Ego feminino aparentemente comanda o sistema. Chamo minha prima cruzada matrilateral de mãe por ela ser a xará da minha mãe. Os demais termos para primos cruzados completa o mesmo racioncínio - meu primo cruzado mãe por ela ser a xará da minha mãe. Os demais termos para primos cruzados completa o mesmo racioncínio - meu primo cruzado
matrilateral é um irmão da mãe, e meus primos cruzados patrilaterais são filhos, porque me chamam de mãe. Maiores detalhes sobre o sistema onomástico podem ser encontrados em Lea 1986 e 1992

Este artigo fornece poucos exemplos dos termos triádicos porque sua análise parte, inevitavelmente, do entendimento daquilo descrito aqui como os termos básicos (ou elementares) de referência. Na literatura antropológica, a terminologia de parentesco Mẽbengôkre é designado, de modo geral, como do tipo Omaha, uma categoria cuja discussão aprofundada esgotaria os limites deste artigo ${ }^{8}$ Em resumo,

${ }^{7}$ As listas completas de todas as formas de termos de parentesco Mẽbengôkre podem ser encontradas em Lea, 1986, capítulo IV. Ouvi mais uns três termos triádicos numa ida ao campo em 2002. No entanto, o clima de cobrança monetária para qualquer informação foi tão carregado que desisti de registrá-los.

${ }^{8}$ Rivière (1980: 537) afirma que o material Jê problematiza a tipologia (Crow-)Omaha, uma questão que extrapola os limites deste texto, e que não modificaria a análise sendo realizada aqui. 
uma das características deste tipo de terminologia é que não emprega o princípio geracional; por exemplo, o termo nhênget (ver diagrama) é usado para o tio materno, o avô materno e paterno, e o primo cruzado matrilateral, além de outras posições genealógicas mais distantes. O irmão do pai é classificado como um pai (bam), ou seja, na terminologia antropológica, é um pai classificatório, e a irmã da mãe é uma mãe classificatória. Estes poucos exemplos são suficientes para demonstrar a dificuldade de fornecer glosas adequadas em português (ou outra língua qualquer).

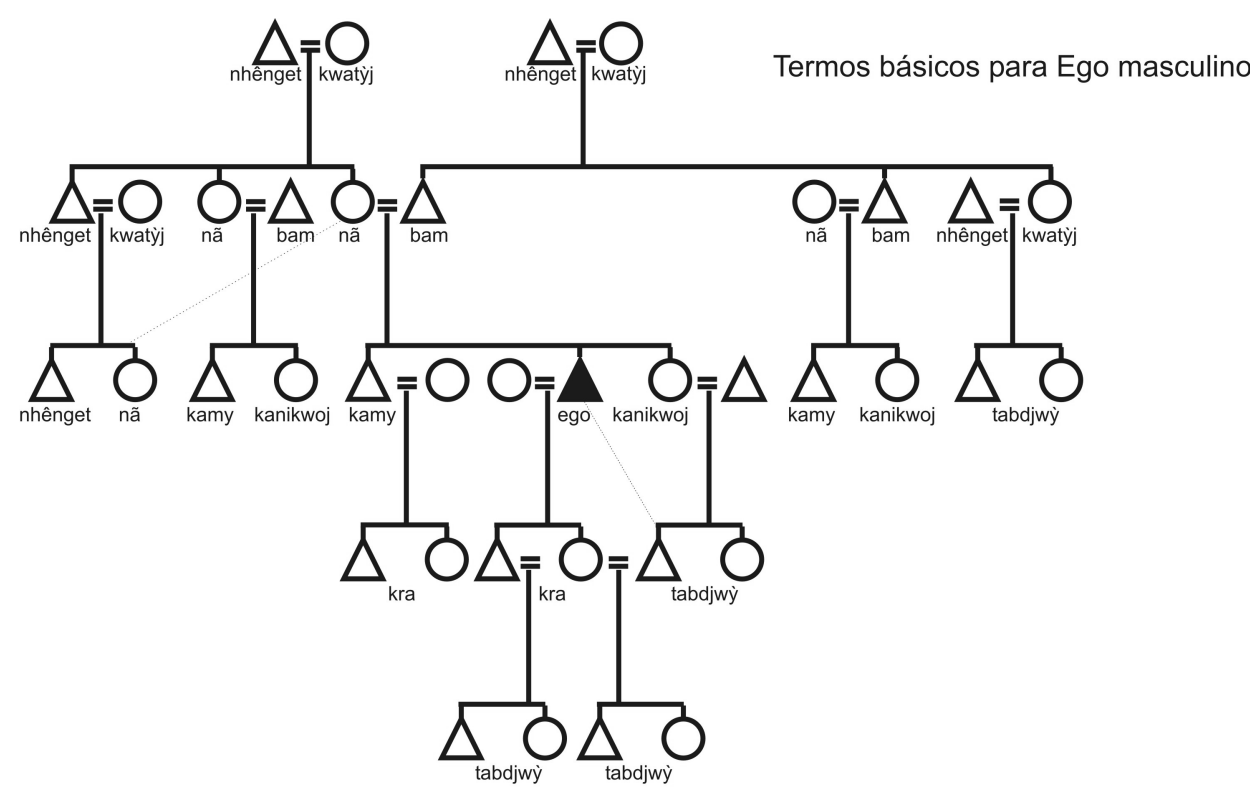

As linhas quebradas indicam a transmissão de nomes, de uma mulher à filha do irmão, e de um homem ao filho da irmã.

Para voltar ao exemplo no meu diagrama, a glosa 'tua sobrinha = minha filha' é uma simplificação para facilitar o entendimento dos não-especialistas. Trata-se, na realidade, de 'teu tabdjwỳ' (filha da irmã para $O^{7}$; filha do irmão para O; neta para ambos os sexos). ${ }^{9}$ Já tentei discutir os termos triádicos com um matemático e um filósofo (respectivamente), mas desistiram do assunto. Héritier (1989), partindo de um trabalho anterior de Murdock, sintetiza uma terminologia Omaha com um diagrama demonstrando que, para uma determinada pessoa (Ego), os primos paralelos (filhos de dois irmãos ou de duas irmãs) são designados como germanos (são irmãos e irmãs classificatórios). Os primos cruzados (filhos de um irmão e uma irmã) matrilaterais são designados por termos que remetem a uma ou mais gerações ascendentes. No

${ }^{9}$ Embora o termo tabdjwỳ seja usado para ambos os sexos, há termos triádicos distintos para

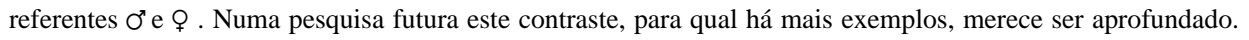


caso Mẽbengôkre, a prima cruzada matrilateral (MBD) ${ }^{10}$ é classificada como uma mãe, e o primo cruzado matrilateral (MBS) como um irmão da mãe, ou avô. Os primos cruzados patrilaterais (FZD/FZS) são classificados como filhos por Ego feminino, e como filhos da irmã, ou netos, por Ego masculino. Note-se a congruência no que diz respeito à classificação dos primos cruzados - o recíproco de mãe é filho/ $/ a^{11}$, e o recíproco de irmão da mãe (ou avô) é filho/a da irmã (ou neto/a). Bastam estas informações (que podem ser decifradas pelos diagramas dos termos básicos), para o leitor entender que encerramos aqui a discussão da terminologia básica para poder enfocar apenas os termos triádicos no restante do artigo.

\section{Interpretando os termos triádicos}

Será tratada, primeiramente, a questão da lógica. ${ }^{12}$ Em português ou em inglês, por exemplo, se eu (como Ego feminino) estou falando com minha irmã a respeito da minha filha, posso perguntar "Você viu minha filha?" ou "Você viu tua sobrinha?" Ambas as possibilidades soam estranhas porque minha filha é simultaneamente a sobrinha da minha irmã. Poderia evitar este embaraço perguntando: "Você viu Fulana?" (ou seja, empregando o nome pessoal da minha filha). É uma estratégia que deixa de lado os relacionamentos entre as três pessoas envolvidas. Certas, se não todas, línguas Jê, e dos aborígenes australianos, desenvolveram termos específicos que apontam simultaneamente para duas ou três relações, ou ressaltam duas relações, deixando inferir a terceira. Em mẽbengôkre, no contexto do exemplo citado, diria akadjwojtx / akadjwojte. Analiso tais termos como uma equação, no sentido de significar, neste exemplo: Tua 'sobrinha' (filha classificatória) = minha filha. ${ }^{13}$

A analogia mais próxima em inglês ou português demonstra a inferioridade da lógica empregada nesta estratégia. Vejamos, Merlan (1989:228) exemplifica a modulação de perspectiva, tal como existe em inglês, quando um pai se dirige ao filho, referente a sua própria cônjuge, dizendo "mummy...". Este mesmo fenômeno pode ser observado em português.

A ênfase num conjunto de relações envolvendo o locutor, interlocutor e referente evoca Strathern $(1988,1995)$, quando insiste que na Melanésia uma pessoa nasce como o produto (ou objeto) de relacionamentos, e não como um indivíduo que precisa formar relacionamentos. Ela argumenta que entre os Hageners da Nova Guiné, com quem

\footnotetext{
${ }^{10}$ As abreviações se baseiam na língua inglesa, onde $\mathrm{M}=$ mother (mãe), $\mathrm{F}=$ father (pai), $\mathrm{Z}=$ sister (irmã), B = brother (irmaõ), $\mathrm{D}=$ daughter (filha), $\mathrm{S}=$ son (filho), $\mathrm{H}=$ husband (marido), e W = wife. Em português, é necessário ler as abreviações de trás para frente devido ao uso do apóstrofe em inglês, por exemplo MBD = mother's borther's daughter (filha do irmão da mãe).

${ }^{11}$ Ou seja, chamo de mãe que me chama de filho/a.

${ }^{12} \mathrm{Na}$ apresentação da versão preliminar deste artigo, no II Encontro Macro-Jê, Wilmar Rocha d’Angelis me indagou se tais termos remetem à questão de foco. É uma questão interessante mas que não tenho competência lingüística para responder.

${ }^{13}$ Para comparar a algebra dos Mẽbengôkre com a geometria que se manifesta nas pinturas corporais, vide Lea 2002.
} 
realizou sua pesquisa, chegar à maturidade não significa atingir independência, mas, ao contrário, reconhecer sua interdependência em relação a seus parentes.

McConvell (1982: 100) comenta que alguém usa termos de parentesco não marcados (designados termos comuns por Merlan, 1989) em contextos onde se desconhece a relação entre o locutor, e as outras duas pessoas, ou onde é irrelevante. Pela lógica inversa, é possível inferir que onde há uma relação entre o interlocutor e referente, e entre o referente e locutor, e portanto entre locutor e interlocutor, é imperioso registrar esta triangularidade pelo emprego do termo relevante. Este contraste entre termos básicos (comuns ou não marcados) e triádicos evoca a distinção, encontrada freqüentemente nas línguas indígenas brasileiras, entre pronomes pessoais inclusivas e exclusivas. Os termos triádicos maximizam a inclusividade.

Merlan (1989) pesquisou aquilo que descreve como 'termos especiais' na língua jawoyn, de um povo aborígene situado ao norte da Austrália, em Arnhem, ao suleste de Darwin. Menciona (1989: 230-1) que tais termos multirelacionais são às vezes designados pela palavra yernderr, com a conotação de 'ouvido'. Sugere que a associação pode estar relacionada com a situação de acampamento, onde a vida exposta é sempre caracterizada por uma etiqueta muito desenvolvida de orientação e atenção seletivas em relação aos outros. Comenta (1989: 229) que numa sociedade onde todos são classificados pelo idioma de parentesco, talvez era de se esperar o desenvolvimento de uma terminologia de relacionamento que emprega perspectivas variáveis, ou mais de um ponto de vista simultaneamente. Ao meu ver, a raridade de tais termos desmente isto, ou alternativamente, e com maior probabilidade, até hoje foram reconhecidos por poucos pesquisadores.

Merlan (1989: 227-228) desenvolve sua análise dos termos multirelacionais distinguindo entre os seguintes papéis: locutor-interlocutor-referente,,$^{14} \mathrm{e}$ designa como propositus aquele a partir de quem se calcula a relação. ${ }^{15}$ Emprega apenas uma vez a expressão "triângulo de relações relevantes" (1989: 247), apesar de sintetizar esta perspectiva no seu diagrama. Laughren (1982: 72) discute termos de parentesco equivalentes, denominados por ela de 'trirelacionais', entre os Warlpiri, situados ao noroeste de Alice Springs, no território setentrional da Austrália. Ela usa os mesmos termos de análise que Merlan.

McConvell (1982) analisou aquilo que designa como termos de parentesco compartilhados, ou triangulares, ${ }^{16}$ entre os Gurindji, vizinhos dos Warlpiri. Inicialmente, parece apontar para uma lógica diferente daquilo que encontrei. ${ }^{17}$ No entanto, ao precisar sua descrição, é possível constatar a semelhança do fenômeno

${ }_{15}^{14}$ Em inglês: speaker-addressee-referent.

${ }_{16}$ Em inglês: "person from whom the relation is reckoned" (Merlan, 1989: 227).

16 Ou seja, "shared (triangular) kin terms" (McConvell, 1982:99). Este autor comenta que a expressão 'shared kin terms' foi adotado do trabalho de O'Grady e Mooney (1973), Nyangumarta Kinship Terminology. Anthropological Linguistics 15.1:1-23.

Enquanto os termos triádicos m?bengôkre enfatizam a relação entre interlocutor e referente, e interlocutor e referente, McConvell afirma (1982:99): "The shared terms incorporate not only information about the relationship between the referent (alter) $\mathrm{X}$ and the reference point (propositus) $\mathrm{Y}$, as in ' $\mathrm{X}$ is Y's brother', but also specify the relationship of the speaker to both X and Y." 
registrado na Austrália e no Brasil. ${ }^{18}$ De acordo com McConvell (1982:99), os termos compartilhados marcam três relacionamentos diádicos: entre o locutor e o ponto de referência (ou propositus); entre o locutor e o referente, e entre o ponto de referência e o referente.

Merlan comenta (1989: 228, 260) que a maioria das análises dos termos de parentesco tomam como norma que o locutor seja o propositus, ou seja, que os termos são centrados no falante (speaker centered). Afirma (1989: 228-9) que o propositus pode ser, ou não ser o locutor, ou não se limitar a ele. Em jawoyn, de acordo com esta autora (1989: 259), o propositus geralmente eqüivale à pessoa no papel participante de interlocutor (addressee), o que corresponde aos termos triádicos mẽbengôkre. Merlan nota (1989: 229) que o propositus pode ser gramaticalizado pelo uso de elementos possessivos, como acontece em mẽbengôkre. Complementaria, sugerindo que o locutor se dirige a alguém com um termo precedido pelo prefixo possessivo de segunda pessoa $(a-=$ teu- $)$ como precondição para engajar o outro no papel de interlocutor.

O termo aparil aparire é um exemplo onde o locutor e o interlocutor têm relações diferenciadas relativas ao referente. O termo pode ser glosado pela equação: teu sobrinho (ou neto) atabdjwë = meu filho (ikra).$^{19}$ Apatxe/ apajte é um exemplo onde o locutor e o interlocutor têm a mesma relação com o referente; pode ser glosado pela equação: teu tabdjwë (sobrinho ou neto $)=$ meu tabdjwë. Do meu ponto de vista, tratase de uma equação que formulei inicialmente da seguinte forma: 'teu $\mathrm{x}=$ meu $\mathrm{y}^{\wedge}$ resultado $\mathrm{z}$ ', ou 'teu $\mathrm{x}+$ meu $\mathrm{y}=\mathrm{z}$ '. Um graduando em matemática sugeriu a equação lógica seguinte: $\left[\right.$ teu $(x)^{\wedge}$ meu $\left.(x)\right] \Longleftrightarrow[z(x)] .{ }^{20}$

Um exercício feito freqüentemente no campo de estudos estruturalistas de parentesco é examinar quais combinações logicamente possíveis são realizadas de fato, quais não são, e por quê. Não consegui ainda realizar este exercício exaustivamente, mas é interessante constatar que nem todas as possibilidades lógicas de combinações foram encontradas, pelo menos até este momento. Por exemplo, aparentemente não existe um termo que expresse 'tua mãe é minha irmã' (portanto, você é minha filha classificatória), nem 'teu pai é meu irmão' (portanto, você é meu sobrinho), nem 'tua irmã é minha filha' (portanto, você é minha filha). Futuramente, testar todas as lacunas existentes poderia auxiliar a apuração da lógica triádica. McConvell (1982:99) constata que, na língua dos Gurindji, apenas aproximadamente a metade das combinações logicamente possíveis entre locutor, ponto de referência, referente, é coberta por termos de parentesco compartilhados.

${ }^{18}$ McConvell (1982:99) esclarece [compare com nota anterior] "Actually, it is only necessary to specify the speaker's relationship to one of the other two, since from knowledge of the speaker's relationship to $\mathrm{X}$ and of $\mathrm{X}$ 's relationship to $\mathrm{Y}$ we can compute the speaker's relationship to $\mathrm{Y}$ (and viceversa)."

${ }^{19}$ A maioria dos termos triádicos é indecifrável, com a exceção de apari (teu sobrinho /neto = minha filha). Há um homófono que significa 'teus pés', e o imperativo para 'coloque-o no chão!' (por exemplo, contexto de uma panela que começa a ferver no fogo de cozinhar) é apari mã adja (teus pés + beneficiário + prefixo de segunda pessoa + colocar). Há várias metáforas corporais para designar relações de parentesco, mas não há espaço para aprofundar o assunto neste artigo.

${ }^{20}$ Agradeço Luciana Dourado por ter solicitado o auxílio do filho dela (Flávio Botelho) para melhorar a formulação da equação. 
Merlan (1989: 230) considera que, no que diz respeito à classificação de parentes na Austrália, as classes semânticas são potencialmente menos precisas em termos denotativos que outros sistemas de parentesco. Isto porque um mesmo referente pode ser denotado simultaneamente por formulações distintas: "minha mãe versus tua tia versus nossa parente mútua." Esta mesma autora comenta (1989: 247) que, embora os termos especiais não designem o referente inequivocamente, os interlocutores geralmente não solicitam esclarecimentos. No entanto, às vezes o locutor faz comentários que podem ajudar a identificar o referente.

Os termos triádicos mẽbengôkre, por seu viés erudito, são usados de forma retórica em discursos públicos onde não há um referente determinado. Em tais casos, cada ouvinte pode pensar na categoria apropriada de parente, como seus nhênget de forma geral. Um exemplo hipotético (de Lea 1986: 263), de uma frase típica do gênero de fala do tipo sermão (mẽ akre), é o seguinte: "Vocês mulheres devem pegar mais lenha para esquentarem teus filhos que são meus filhos classificatórios (akamrere), e teu marido que é meu genro/ cunhado $[\mathrm{ZH}]^{21}$ (arikràm). Teus avôs/irmãos da mãe que são meus cunhados ou genros (amàjngete) estão com frío na casa dos homens por falta de lenha." Na narração de mitos, os termos triádicos são também usados com freqüência. No mito da origem dos nomes bonitos, por exemplo, quando um homem fala com seu irmão a respeito do filho da irmã, usa o termo apatxe, que glosei (Lea, 1984: 263) como "nosso sobrinho", mas na realidade trata-se da equação 'teu sobrinho (ZS) que é meu sobrinho' (ZS) ${ }^{22}$ As pessoas mais velhas usam tais termos no cotidiano, mais uma das minhas interlocutores (Kôkônhere), relativo a esta questão, me disse que as pessoas mais novas não os usam com tanta frequiência. Se essa afirmação não for um exagero, seria interessante saber se o fato se deve à sabedoria dos velhos (acumulada ao longo da vida), ou se os termos triádicos estão começando a cair em desuso, associado ao processo de fascínio pelo mundo dos brancos por parte dos jovens, que não estariam empenhados em dominar nuances tão complexos da arte da fala mais refinada. Por isto acho que seria interessante mapear os termos triádicos e inclui-los no currículo escolar, para exemplificar uma forma de etno-lógica. ${ }^{23}$

Merlan nota (1989: 248) que, em comparação com os termos comuns, há um grau de neutralização nos termos especiais, algo que poderia esclarecer os termos que não consegui reduzir a uma única equação. Por exemplo, o termo gàdjwojtxel gàdjwojte (se entendi corretamente) corresponde à equação 'tua mãe é minha 'ypỳjn (cunhada [WZ]...), ${ }^{24}$ ou 'ypỳjndjwë sogra (WM...)'. Nos termos triádicos mẽbengôkre, no abstrato (fora de

${ }^{21}$ O termo 'cunhado' é uma glosa grosseira porque o marido da irmã (udjwỳ) naõ é equivalente ao irmão da esposa (umre) em mẽbengôkre.

${ }^{22} \mathrm{O}$ homem fala: “...ga ne ga apatxe ami jarì" (é você que deu teu nome para nosso sobrinho); você enfático (ga ne ga) / nosso sobrinho (apatxe) / beneficiário (mã) / reflexivo (ami) / contar (jarẽ). Vide Lea 1986: 78 .

${ }^{23}$ Prestei atenção nos termos triádicos no campo em 2002. Foram usados abundantemente por pessoas de várias idades, e foi afirmado que constituem a fala verdadeira, dos amigos. Em outras palavras, são reconhecidos como uma categoria cultural valorizada. Os professores bilíngües me censuram de tratar o assunto na escola, dizendo que era um assunto para tratar com seus velhos, não com uma kubẽ (branca).

${ }^{24}$ Reticências indicam que o termo se aplica a outras posições genealógicas também. 
40

contexto), nem o locutor, interlocutor, nem referente é unívoco, e isto dificulta a diagramação (veja a seguinte lista de usos de um termo). Os termos mẽbengôkre são polissêmicos, portanto, a relação entre locutor e interlocutor não pode ser inferida pelo pesquisador. ${ }^{25}$ Por exemplo, encontrei os sete seguintes usos possíveis para o termo akamrere/ akamrerere, que corresponde à equação 'teu filho = meu filho', sem garantia de ter esgotado suas possibilidades semânticas:

O falando com sua irmã a respeito da filha desta * 26

O falando com sua irmã a respeito de seu próprio filho *

O falando com seu marido a respeito do HBS

$\sigma^{\pi}$ falando com seu irmão a respeito do filho deste *

$\sigma^{\prime \prime}$ falando com seu irmão a respeito de seu próprio filho *

$\sigma^{7}$ falando com sua esposa a respeito da WZS

$\sigma^{\pi}$ falando com a irmã de sua esposa a respeito do próprio filho

Esta lista reforça a afirmação de que a multiplicidade de usos de um termo triádico qualquer é reduzível a uma equação, porque evidentemente seria impossível para as pessoas ficar decorando, um a um, os usos da soma dos termos triádicos. Decorar quarenta e uma equações já é uma tarefa considerável, lembrando que há possivelmente mais alguns termos triádicos ainda não registrados.

Merlan (1989: 238) discute quais categorias de parente podem ser discutidas na língua jawoyn no abstrato. Comenta (1989: 261. n 9) que um dos motivos que dificultou a explicação dos termos especiais pelos falantes é que não são apenas dialógicos (dialogic) “codificam uma dimensão referencial adicional." ${ }^{, 27}$ McConvell (1982:99), como Merlan (1989), menciona que os termos triangulares não ocorriam naturalmente em sessões de elicitação. Numa descrição apta, Merlan fala de explicações de informantes retrocedendo aos termos comuns que "achatam a natureza multidimensional dos termos especiais" (1989: 247). Na minha pesquisa, procurei relações genealógicas concretas para exemplificar os termos fornecidos por Vidal, para checá-los com determinada informante. Depois inverti o processo, perguntando com quais pessoas minha informante usaria determinados termos. Detectei vários termos ainda não registrados ao ouvi-los sendo usados, e encontrei mais alguns ao perguntar para alguém como falaria com fulano a respeito de sicrano, mapeando de antemão a relação entre as três pessoas em questão.

Merlan afirma (1989: 229) que Austrália fornece os exemplos mais complexos, conhecidos até então, de lexicalizações especiais, onde "the socially recognized relationship of speaker to both propositus and referent is often implicated..." Os termos triádicos dos Mẽbengôkre são tão complexos quanto os termos australianos, mas, de qualquer maneira,

25

Merlan (1989: 245), num contexto de casamento prescritivo entre primos, dá um exemplo de uma mulher se dirigindo a outra mulher com um termo que tem a conotação de 'teu cônjuge, meu germano'. Diz que pode ser inferido, ou melhor, o emprego do termo pressupõe que a locutora e interlocutora são primas.

${ }^{26} \mathrm{O}$ asterisco indica quais usos foram incorporados da lista dos termos citados por Vidal (1977: 58).

27 Em inglês: "but encode an added referential dimension." 
o diálogo com os aborígenes, empreendido via Merlan, e os demais pesquisadores da Austrália mencionados neste artigo, deu um estímulo enorme para aprofundar sua análise.

Encerro este artigo sugerindo (por enquanto, apenas na base da intuição) que uma pista para aprofundar a análise dos termos triádicos seria via a discussão de Lévi-Strauss sobre estruturas ternárias e princípios triádicos, no contexto da formulação de dualismo diametral versus dualismo concêntrico (onde emprega um triângulo num dos diagramas). Conclui o ensaio clássico 'Les organisations dualistes existent-elles?', sugerindo "traiter les formes apparentes de dualisme comme des distorsions superficielles de structures dont la nature réelle est autre, et beaucoup plus compliquée." (1958: 179). ${ }^{28}$ Para ajustar esta afirmação ao contexto atual, repetiria apenas que, se minha perspectiva for correta, os termos triádicos mẽbengôkre foram elaborados a partir dos termos elementares. ${ }^{29}$ No entanto, na medida em que a discussão de Lévi-Strauss abrange o que poderiamos chamar de princípios filosóficos, não seria surpreendente descobrir que afloram no campo da terminologia de parentesco, justamente na forma dos termos triádicos.

\section{Agradecimento}

Quero agradecer Kôkônhere e sua filha Kena pela paciência que demonstraram em discutir os termos triádicos comigo durante horas a fio, no decorrer de várias sessões de trabalho. Agradeço Marcela Coelho de Souza por ter me dado uma cópia do artigo de Merlan (1989), e por ser a primeira pessoa que não meramente franziu a testa quando tentei explicar um fenômeno que me fascina tanto. Agradeço o CNPq, FAPESP, FAEP, FINEP, e a Fundação Wenner-Gren pelo apoio financeiro ao longo dos anos. Por último, agradeço Wilmar Rocha D' Angelis porque o evento que organizou me deu o estímulo para retomar uma questão engavetada há muito tempo.

\section{BIBLIOGRAFIA}

DREYFUS, S. (1963). Les Kayapo du Nord: Contribution à l'étude des Indiens Ge. Paris \& The Hague: Mouton \& Co, 1963.

HÉRITIER, Françoise. (1989). Enciclopédia Einaudí 20. Parentesco. Parentesco. Lisboa: Imprensa Nacional/Casa da Moeda, [1979], 1989.

LAUGHREN, Mary. (1982). Warlpiri Kinship Structure. In Languages of Kinship in Aboriginal Australia, organizado por J. Heath, F. Merlan e A. Rumsey, 72-85. Sydney: Oceania Linguistic Monographs.

LEA, V. (1984). The origin of ceremonially endowed names (Txukarramãe). In Folk Literature of the Gê Indians, vol.2. J. Wilbert e K. Simoneau (orgs.). Los Angeles: UCLA.

${ }^{28}$ Vide também Viveiros de Castro 1996, 1998.

${ }^{29}$ Nas palavras de Merlan (1989: 244), os termos comuns exprimem uma relação entre um referente e um propositus - que pode ou não ser o falante. Um exemplo, em português, seria 'minha mãe', versus 'tua mãe'). 
.(1986). Nomes e nekrets Kayapó: uma concepção de riqueza. Museu Nacional, Universidade Federal de Rio de Janeiro. Tese de doutorado.

(1992). M?bengokre (Kayapó) personal names - total social facts in Central Brazil. Man, Londres. Vol.27 (NS), no 1, p. 129-153.

(2002). O corpo como suporte para a geometria. In: Idéias Matemáticas de Povos Culturalmente Distintos. Mariana K. Leal Ferreira (org.). São Paulo: Centro Mari-USP/ Editora Global.

LÉVI-STRAUSS, Claude. (1958). Les organisations dualistes existent-elles? In: Anthropologie Structurale. Paris: Plon, [1956].

MERLAN, Francesca. (1989). Jawoyn Relationship Terms: Interactional Dimensions of Australian Kin Classification. Anthropological Linguistics 31, nos. 3-4, p, 227-263.

McCONVELL, Patrick. (1982). Neutralisation and Degrees of Respect in Gurindji. In Languages of Kinship in Aboriginal Australia, organizado por J. Heath, F. Merlan e A. Rumsey, 86-105. Sydney: Oceania Linguistic Monographs.

McGREGOR, William. (1996). Dyadic and Polyadic Kin Terms in Gooniyandi. Anthropological Linguistics Vol.38, $\mathrm{n}^{0} 2$, p. 216-247.

RIVIÈRE, P. (1980). Dialectical Societies: Review article. Man 15 (3), p.533-540.

SEEGER, A. (1981). Nature and Society in Central Brazil: The Suyá Indians of Mato Grosso. Cambridge MA.:Harvard Univ. Press.

STOUT, M. \& THOMSON, R. (1974). Fonêmica Txukahamei (Kayapó). Série Lingüística 3.

STRATHERN, M. (1988). The Gender of the Gift: Problems with Women and Problems with Society in Melanesia. Berkeley: Univ. of California Press.

.Necessidade de pais, necessidade de mães. Estudos Feministas. Ano 3 n ${ }^{0}$ 2, p.303-329, 1995. Versão original em inglês, manuscrito: 1992. 'Needing fathers, needing mothers'.

TURNER, T. (1966). Social Structure and Political Organization among the Northern Kayapó. Universidade de Harvard. Tese de Doutorado.

VIDAL, L. (1977). Morte e Vida de uma sociedade Indígena Brasileira. São Paulo: Hucitec.

VIVEIROS DE CASTRO, E. (1996). Ambos os Três: sobre algumas distinções tipológicas e seu significado estrutural na teoria do parentesco. Anuário Antropológico - 95. Rio de Janeiro: Tempo Brasileiro. .Dravidian and related kinship systems. In: Godelier, M., Trautman, T.R., e Tjon Sie Fat, F. (orgs.) Transformations of Kinship. Washington: Smithsonian Institution Press, 1998. [Corresponde à versão inglesa da referência anterior]. 